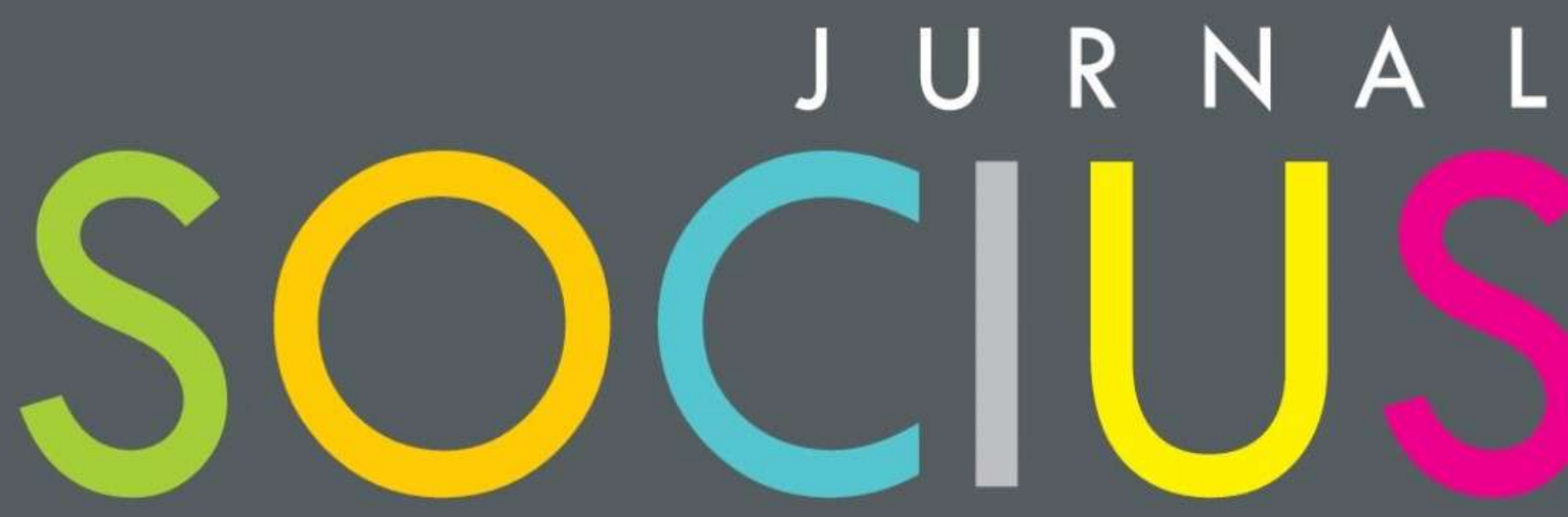

Journal of Sociology Research and Education

DITERBITKAN OLEH :

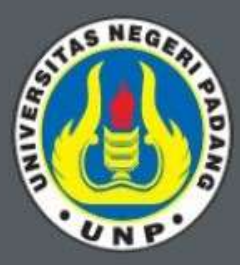

LABOR JURUSAN SOSIOLOGI FAKULTAS ILMU SOSIAL UNIVERSITAS NEGERI PADANG

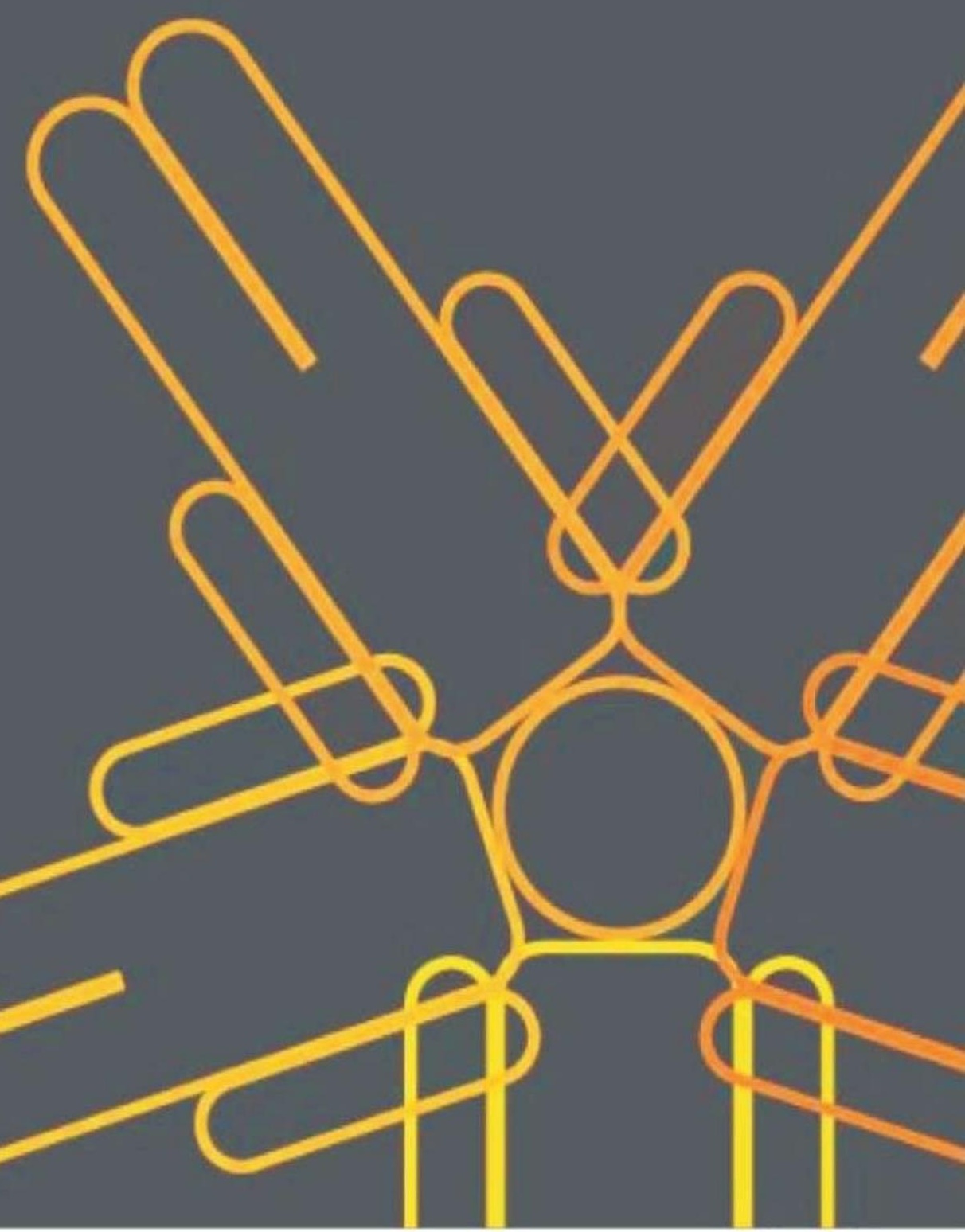




\section{SOCIUS}

Vol. 4, No.2, Th. 2017

ISSN : 2356-4180 (cetak)

2442-8663 (online)

\begin{tabular}{|c|c|}
\hline $\begin{array}{c}\text { REDAKSI } \\
\text { JURNAL SOCIUS }\end{array}$ & DAFTAR ISI \\
\hline $\begin{array}{l}\text { Ketua Dewan Penyunting : } \\
\text { Dr. Erianjoni, S.Sos., M.Si. } \\
\text { Wakil Ketua Dewan Penyunting : } \\
\text { Selinaswati, S.Sos., M.A., Ph.D. }\end{array}$ & $\begin{array}{c}\text { Abdul Salam } \\
\text { Bulan Bintang dibawah Kuasa Beringin: Parmusi } \\
\text { Padang Pariaman Masa Orde Baru } \\
\text { Halaman 61-73 }\end{array}$ \\
\hline $\begin{array}{c}\text { Dewan Penasehat: } \\
\text { Prof. Dr. Syafri Anwar, M.Pd. } \\
\text { (Universitas Negeri Padang) } \\
\text { Prof. Dr. Mestika Zed, MA. } \\
\text { (Universitas Negeri Padang) } \\
\text { Prof. Dasman Lanin, M.Pd., Ph. D. } \\
\text { (Universitas Negeri Padang) } \\
\text { Bakhrul Khair Amal, SE.,M.Si. } \\
\text { (Universitas Negeri Medan) } \\
\text { Prof. Dr. Ferdinand Kerebungu, M.Si. } \\
\text { (Universitas Negeri Manado) } \\
\text { Dr.rer.nat. Nurhadi, S.Ant., M. Hum. } \\
\text { (Universitas Negeri Solo) } \\
\text { Drs. Emizal Amri, M.Pd., M.Si. } \\
\text { (Universitas Negeri Padang) } \\
\text { Adri Febrianto, S.Sos., M.Si. } \\
\text { (Universitas Negeri Padang) } \\
\text { Drs. Ikhwan, M.Si. } \\
\text { (Universitas Negeri Padang) }\end{array}$ & $\begin{array}{c}\text { Delmira Syafrini dan Reno Fernandes } \\
\text { Dampak Revitalisasi Kota Sawahlunto Dari } \\
\text { Kota Tambang Menjadi Kota Wisata Tambang Berbudaya Pada } \\
\text { Kehidupan Sosial Ekonomi Masyarakat } \\
\text { Kota Sawahlunto } \\
\text { Halaman } 74-82 \\
\\
\text { Erda Fitriani, Selinaswati dan Desy Mardhiah } \\
\text { Partisipasi Masyarakat Dalam Pembangunan } \\
\text { Ekowisata Sungai Pinang } \\
\text { Studi Kasus: Nagari Sungai Pinang Kecamatan Koto IX Tarusan } \\
\text { Kabupaten Pesisir Selatan Sumatera Barat } \\
\text { Halaman } 83-96 \\
\text { Erianjoni } \\
\text { Pengembangan Materi Ajar Sosiologi Tentang Mitigasi Bencana } \\
\text { Berbasis Kearifan Lokal Di Kota Padang } \\
\text { Halaman 97-108 }\end{array}$ \\
\hline $\begin{array}{l}\text { Dewan Penyunting: } \\
\text { Dr. Eka Vidya Putra,S.Sos,.M.Si. } \\
\text { Dr. Desy Mardiah,S.Sos..S.Thi,.M.Si } \\
\text { Ike Sylvia,S.IP,.M.Si. } \\
\text { M. Isa Gautama,S.Pd,.M.Si. } \\
\text { Reno Fernandes, S.Pd., M.Pd. }\end{array}$ & $\begin{array}{c}\text { Muhammad Hidayat } \\
\text { Studi Pengaruh Kemandirian Mahasiswa Yogyakarta Terhadap Perstasi } \\
\text { Akademik: Respon } 60 \text { Mahasiswa Di Yogyakarta } \\
\text { Halaman 109-119 }\end{array}$ \\
\hline $\begin{array}{c}\text { Layout Editor : } \\
\text { Rhavy Ferdyan, S.Pd. }\end{array}$ & $\begin{array}{c}\text { Reno Fernandes } \\
\text { Adaptasi Sekolah Terhadap Kebijakan Pendidikan Inklusif } \\
\text { Halaman 120-126 }\end{array}$ \\
\hline $\begin{array}{l}\text { Technical Support: } \\
\text { Rudi Mahesa, A.Md. }\end{array}$ & $\begin{array}{c}\text { Selinaswati dan Erda Fitriani } \\
\text { Peran Sekolah Dalam Antisipasi Keracunan } \\
\text { Pangan Jajanan Anak Sekolah-PJAS }\end{array}$ \\
\hline $\begin{array}{l}\text { Alamat Redaksi: } \\
\text { Jurusan Sosiologi FIS UNP } \\
\text { Jl. Prof.Dr.Hamka } \\
\text { Kampus UNP Air Tawar } \\
\text { e-mail: } \underline{\text { sosan@ @is.unp.ac.id }}\end{array}$ & $\begin{array}{c}\text { (Studi Kasus Tiga SD Di Air Tawar Timur Padang Sumatera Barat) } \\
\text { Halaman 127-134 }\end{array}$ \\
\hline $\begin{array}{l}\text { Penerbit } \\
\text { Labor Jurusan Sosiologi } \\
\text { Universitas Negeri Padang }\end{array}$ & \\
\hline
\end{tabular}




\title{
DAMPAK PERGESERAN KEBIJAKAN KOTA TAMBANG MENJADI KOTA WISATA TAMBANG BERBUDAYA PADA KEHIDUPAN SOSIAL EKONOMI MASYARAKAT DI KOTA SAWAHLUNTO
}

\author{
Delmira Syafrini ${ }^{1}$, Reno Fernandes ${ }^{2}$ \\ 1,2 Universitas Negeri Padang \\ Email: delmirasyafrini@ymail.com, noe_nandes@yahoo.com
}

\begin{abstract}
Abstrak
Artikel ini mengkaji tentang dampak dari pergeseran kebijakan kota tambang menjadi kota wisata tambang berbudaya di Kota Sawahlunto Sumatera Barat. Topik ini menarik untuk di bahas karena Sawahlunto adalah kota yang pernah dikenal dunia sebagai kota tambang batubara, namun mengalami depresi pasca reformasi di Indonesia akibat menipisnya cadangan batu bara. Namun saat ini Kota Sawahlunto bangkit kembali dengan mengubah arah pembangunan kota, melalui visi "Sawahlunto tahun 2020 menjadi kota wisata tambang berbudaya". Perubahan kebijakan di kota ini ternyata mampu membangkitkan Kota Sawahlunto dari keterpurukan, terbukti dari membaiknya kembali kehidupan kota yang hampir menjadi 'kota mati' ini. Baik kehidupan sosial maupun perekonomian masyarakat yang terbukti dengan menurunnya angka kemiskinan dari tahun ke tahun di Kota Sawahlunto.
\end{abstract}

Kata Kunci: Kota Sawahlunto, Kota Tambang, Kota Wisata Tambang

Abstract
This article examines the impact of the mine policy shift into a cultured mining town in Sawahlunto Town of West Sumatra. This topic is interesting to discuss because Sawahlunto is a city once known as a coal mining town, but experiencing post-reform depression in Indonesia due to depletion of coal reserves. But now the city of Sawahlunto bounced back by changing the direction of urban development, through the vision of "Sawahlunto in 2020 into a cultured mining town". The change of policy in this city was able to raise the city of Sawahlunto from the downturn, as evidenced by the recovery of city life which almost become 'ghost town'. Both social life and society economy which is proven by the decreasing of poverty year by year in Sawahlunto Town.

Keywords: Sawahlunto Town, Mining Town, Heritage Mining Tourisme Town

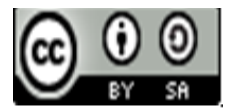

Received: July 28, 2017 Revised: October 14, 2017 Available Online: December 1, 2017

\section{Pendahuluan}

Sawahlunto adalah kota kecil yang terletak di Sumatera Barat yang memiliki perjalanan sejarah yang sangat unik. Bermula dari kota yang terkenal dengan kota tambang hingga dijuluki sebagai Kota Arang atau Kota Emas Hitam karena potensi batu bara yang melimpah. Bahkan pernah menyandang sebutan kota industri batubara ternama dunia semenjak pertama kali ditemukannya oleh seorang geologi Belanda bernama Willem Hendrik De Greve pada tahun 1868 (Erman, 2005). Akan tetapi saat ini wajah Kota Sawahlunto telah berubah drastis 
menjadi kota wisata tambang berbudaya. yang menopangkan kehidupan perekonomian masyarakatnya pada sektor pariwisata bukan lagi sektor pertambangan seperti sedia kala.

Menipisnya sumber daya batubara adalah faktor utama perubahan arah kebijakan pembangunan Kota Sawahlunto, yang bermuara pada revitalisasi Kota Tambang menjadi Kota Wisata Tambang Berbudaya. Beratus tahun lamanya batubara menjadi penggerak kehidupan masyarakat Kota Sawahlunto, namun pada tahun 1998 kejayaannya mulai tumbang. Pamor emas hitam redup, hasil batubara merosot tajam dan puncaknya pada 2000 kegiatan tambang batubara ditinggalkan. Hal itu praktis membuat kota kecil ini goyah dari segi perekonomian karena lebih dari $80 \%$ penduduknya bergantung pada sektor pertambangan. Bahkan semakin rendahnya harapan hidup di Kota ini arus migrasi menjadi meningkat drastis dimana dalam kurun waktu 2003-2005 lebih dari 10.000 jiwa meninggalkan kota ini. Kondisi ini diperparah dengan naiknya angka kemiskinan sampai $10 \%$ dan pertumbuhan ekonomi yang minus. Kota emas hitam ini terancam menjadi kota mati seiring berakhirnya masa keemasan tambang batubara peninggalan Pemerintah Kolonial Belanda. (BPS Kota Sawahlunto, 2014)

Mandeknya perekonomian masyara kat Sawahlunto saat itu, hingga dijuluki sebagai 'kota mati' tidak serta merta membuat matinya pula kreativitas pemerintahan Sawahlunto. Pemerintahan Sawahlunto pun berbenah, dengan mengubah kebijakan pembangunan kota dari Kota Tambang menjadi Kota Wisata, yang tertuang dalam rumusan visi Kota Sawahlunto dalam Perda Nomor 2 tahun 2001 yaitu "Sawahlunto Tahun 2020 menjadi Kota Wisata Tambang yang Berbudaya". Visi tersebut kemudian dikukuhkan lagi dengan Perda Nomor 6 tahun 2003 tentang Rencana Strategis Pemerintah Kota Sawahlunto tahun 2003-2008 yang merupakan visi dan misi jangka panjang Pemerintah Kota Sawahlunto sampai tahun 2008 di bidang pariwisata. (BAPPEDA Kota Sawahlunto 2014).

Perwujudan visi Sawahlunto tahun 2020 menjadi kota wisata tambang berbudaya ini bermuara pada pengembangan potensi pariwisata sejarah tambang yang berlandaskan nilai-nilai budaya dengan mengoptimalkan berbagai potensi lokal dengan basis pembangunan sumber daya manusia di Sawahlunto. Maka untuk itu potensi wisata yang dimaksud justru muncul dari sisa-sisa aktivitas penambangan yang sempat terabaikan, diantaranya berupa bangunan bekas penambangan, lobang galian yang sebenarnya berasal dari kerusakan ekologi akibat penggalian secara terus menerus yang didaur ulang kembali menjadi objek wisata yang menarik. Untuk melengkapi pesona wisata tambang ini, ikon wisata juga dilengkapi dengan wisata sejarah yang mengisahkan tentang kisah kelam di balik perjuangan para buruh tambang mereka kenal dengan istilah 'orang rantai' untuk mengisi sisi pengetahuan pada wisatawan.

Perubahan wajah Kota Sawahlunto semakin dikuatkan pula dengan konsep wisata berbudaya, dengan memanfaatkan potensi budaya lokal yang latar belakang masyarakat multietnis sebagai bagian dari sejarah panjang dari aktivitas pertambangan di kota ini. Wisata budaya multietnis ini lah yang juga menjadi ciri khas dari wisata tambang kota Sawahlunto saat ini, dan menjadi daya tarik tersendiri bagi pengembangan pariwisata di Kota Sawahlunto yang berbeda dari kota wisata tambang lainnya di dunia.

Perpaduan antara potensi alam, potensi sejarah dan potensi budaya inilah yang dikemas oleh pemerintahan Sawahlunto saat ini sebagai Kota Wisata Tambang Berbudaya yang nyatanya sukses membangkitkan kembali sejarah kejayaan Kota Sawahlunto, terbukti dengan menurunnya angka kemiskinan masyarakat dari tahun ke tahun. Bahkan akhir 2016 silam Kota Sawahlunto dinyatakan sebagai kota dengan angka kemiskinan nomor dua terendah setelah Kota Tangerang dimana PAD tertinggi justru diperoleh dari ekonomi kerakyatan di bidang jasa dan pariwisata.

Dari kondisi di atas tidak berlebihan jika kita mengambil kesimpulan bahwa pergeseran kebijakan Kota Sawahlunto menjadi Kota Wisata Tambang Berbudaya berhasil mengubah wajah Kota Sawahlunto saat ini, sekaligus membangkitkan kembali perekonomian kota yang 
sempat mati suri. Tulisan ini akan mendeskripsikan bagaimana dampak pergeseran kebijakan kota tambang menjadi kota wisata tambang terhadap kehidupan social ekonomi masyarakat lokal Kota Sawahlunto saat ini.

\section{Metodologi Penelitian}

Penelitian ini dilakukan di Kota Sawahlunto, karena kota ini merupakan satu-satunya kota tambang batubara yang berhasil direvitalisasi menjadi kota wisata di Indonesia dan berhasil meningkatkan kembali kesejahteraan masyarakatnya. Penelitian ini menggunakan metode kualitatif dengan tipe studi kasus instrinsik. Pengumpulan data menggunakan teknik purposive sampling dengan menetapkan karakteristik informan yang dianggap mampu memberikan informasi tentang Kota Sawahlunto pra dan pasca ditetapkan sebagai Kota Wisata Tambang Berbudaya. Adapun teknik pengumpulan data didapatkan melalui teknik observasi partisipasi, wawancara mendalam serta studi dokumentasi yang didapatkan melalui arsip-arsip sejarah tambang dan wisata Kota Tua Sawahlunto, baik yang tersimpan di institusi terkait maupun dimuseum dan situs-situs yang dijadikan sebagai bagian dari objek wisata. Pengolahan data dilakukan melalui pendekatan interactive analysis dari Miles dan Huberman melalui tahap: pengumpulan data, reduksi data, pengolahatan data dan verifikasi data. (Huberman, 1992).

\section{Hasil Dan Pembahasan}

\section{Kota Wisata Tambang Berbudaya: Menghidupkan Kembali Kota Tambang yang Telah Mati}

Sawahlunto Tahun 2020 Menjadi Kota Wisata Tambang yang Berbudaya. Melalui visi inilah perjalanan perubahan wajah Kota Sawahlunto dimulai. Kota yang sejak abad ke 19 terkenal dengan kejayaan pertambangan batubara tiba-tiba mengubah orientasi pembangunan kota ke sektor pariwisata. Revitalisasi kota arang ini muncul bukan tanpa sebab, karena diawali oleh ide tokoh revolusioner yang saat ini mampu mengubah wajah kota arang ini menjadi lebih bersinar. Salah satu tokoh yang sangat berperan adalah Ir. Amran Nur, Walikota Sawahlunto periode 2003-2013.

Pencetusan ide revitalisasi kota sebenarnya telah dicanangkan sejak tahun 2001 masa kepemimpinan Drs. Subari Sukardi, namun mulai menuai hasil pada masa kepemimpinan Ir. Amran Nur sebagai putera daerah yang melihat kondisi Kota Sawahlunto pada saat itu. Sawahlunto yang semula padat penduduk, karena menjadi salah satu kota industri andalan untuk mencari nafkah, tiba-tiba sepi ditinggalkan oleh lebih dari 10.000 penduduk untuk mengadu nasib ke daerah lain karena harapan hidup masyarakat di Kota ini pada saat itu yang terbilang rendah. Kemiskinan meningkat tajam, banyaknya pengangguran dan terjadinya konflik di Sawahlunto yang menjadi pemicu terjadinya cheos dalam tatanan sosial masyarakat Sawahlunto saat itu.

Kondisi semakin diperparah dengan banyaknya kerusakan ekologi yang muncul akibat aktivitas pertambangan selama ini. Seperti lubang galian tambang yang menjadi sumber limbah, terowongan penggalingan, dan gedung-gedung yang dulu dimanfaatkan sebagai pusat industri batu baru saat itu hanya menjadi kenangan dan gedung lama tanpa penghuni. Berdasarkan kondisi tersebut maka pemerintahan Sawahlunto pada masa itu berfikir untuk menjadikan sisa peninggalan pertambangan tersebut sebagai aset penting dan nilai jual dalam pariwisata.

Bangunan bekas kegiatan penambangan didaur ulang kembali dan dikelola menjadi wisata sejarah (heritage tourism) diantaranya: 1) Terowongan Mbah Suro, yang merupakan lorong bekas penggalian batubara yang pernah ditutup pada tahun 1930an dan dibuka kembali pada tahun 2007. 2) Museum kereta api yang didirikan di bekas stasiun kereta api, yang 
memperlihatkan berbagai peralatan kereta api yang pernah digunakan pada masa pemerintahan Belanda untuk pengangkut batubara. 3) Museum Gudang Ransum didirikan dibekas Dapur umum pada tahun 1894. Dapur itu terdiri dari dapur umum, gudang es, gudang makanan mentah, gudang beras, menara asap dari power Stom dan rumah gudang. 4) Gedung pusat kebudayaan (Art Gallery) sebelumnya bernama gedung society yang didirikan pada tahun 1910 sebagai tempat penampilan kesenian seperti pakaian adat, foto-foto pertunjukan seni alat kesenian dari Sawahlunto. Bukan hanya bangunan fisik saja yang dijadikan daya tarik wisata, tetapi juga sejarah yang terdapat di sepanjang aktivitas pertambangan, seperti sejarah orang rantai yang memperlihatkan sisi kelam dari kekerasan dan eksploitasi yang dulu pernah dialami oleh para pekerja tambang di zaman Belanda.

Selain mendaur ulang sisa bangunan pertambangan, bagian yang tidak kalah penting adalah menjadikan kerusakan ekologi akibat penambangan batubara sebagai bagian dari objek wisata penting seperti tiga danau biru di Sawahlunto yaitu Danau Kandi, Danau Tanah Hitam dan Danau Tandikek. Ketiga danau ini tercipta sebagai akibat penggalian batu bara selama beratus tahun lamanya, yang dulu dianggap sebagai pengrusakan alam, namun sekarang dijadikan sebagai wisata alam yang saat ini dikembangkan menjadi Resort Wisata Kandi.

Pemugaran kembali bekas lokasi dan bangunan pertambangan, membuat wajah Kota Sawahlunto berbeda dengan beberapa tahun yang lalu. Jika lokasi pertambangan dulu, dianggap sebagai tempat yang angker, kotor dan sepi justru saat ini kepadatan mengisi lokasi-lokasi tersebut oleh berbagai pengunjung yang berasal dari luar Kota Sawahlunto. Lobang tambang yang gelap seolah menjadi tempat yang menantang untuk dijelajari, begitu pula lobang-lobang bekas galian tambang yang saat ini menjadi danau yang dijadikan sebagai lokasi yang indah untuk dikunjungi.

Pemugaran lokasi tambang tak berpenghuni ini mendapatkan respon positif dari berbagai lapisan masyarakat baik yang menetap di Kota Sawahlunto, maupun yang sekedar menjadi pengunjung. Bagi masyarakat lokal, ini adalah kesempatan besar untuk membuka lahan pekerjaan baru dan bagi masyarakat luar Kota Sawahlunto, konsep wisata tambang ini menjadi alternatif destinasi wisata yang bukan hanya menyajikan keindahan alam, tapi juga pengetahuan tentang sejarah tambang. Artinya bagi masyarakat revitalisasi Kota Sawahlunto mendatangkan kehidupan baru yang lebih menjanjikan. Hal ini karena pariwisata selain mampu mensejahterakan masyarakat juga mampu memberikan kenyamanan pada lingkungan mereka yang selama ini rusak akibat aktivitas penambangan, dengan memanfaatkan kerusakan dan bangunan tua sebagai sumber daya utama untuk menghidupkan kembali kota tambang yang telah mati ini. Seiring dengannya berkembangnya pariwisata tambang di Kota Sawahlunto, berkembang pula aktivitas masyarakat yang membuat kota ini terasa hidup kembali.

\section{Menguatnya Kembali Identitas Budaya Lokal yang Terpendam}

Pengembangan konsep wisata tambang dan wisata alam dalam pengembangan pembangunan Kota Sawahlunto semakin dikuatkan dengan konsep wisata berbudaya, dengan memanfaatkan potensi budaya lokal yang dulu kurang terkelola dengan baik. Potensi budaya paling menarik adalah latar belakang masyarakat Sawahlunto yang multi etnik. Kota kecil ini dihuni oleh beberapa etnis, diantaranya Etnis Minangkabau, Jawa, Sunda, Bugis, Batak dan Tiongha yang hidup bersama secara rukun dengan tetap menjalankan tradisi dan kepercayaan masing-masing. Keberagaman budaya di Sawahlunto juga tidak terlepas dari sejarah pertambangan di kota ini, sebab kedatangan berbagai etnis ini berawal dari dibukanya Sawahlunto sebagai pusat pertambangan batubara sehingga pemerintah Hindia Belanda mengirim sebanyak 20.000 narapidana di seluruh Indonesia sebagai pekerja paksa. Narapidana tersebut berasal dari berbagai etnis dari seluruh Indonesia yang kemudian 
berkembang dan menetap di Kota Sawahlunto. Hingga dalam perkembangannya Sawahlunto tumbuh menjadi kota multietnis di Sumatera Barat.

Dalam perjalanannya seiring dengan pola interaksi yang terjalin secara intensif antara penduduk asli dan pendatang tercipta hubungan yang bersifat asosiatif. Mereka saling bekerjasama baik sebagai pekerja tambang maupun sebagai penduduk yang sama-sama bertempat tinggal di Kota Sawahlunto. Dalam proses yang selanjutnya terjadilah proses akulturasi antar etnis, baik sebagai akibat pembauran maupun melalui perkawinan campur. Bukti dari terjadinya proses akulturasi ini adalah terciptanya unsur budaya bersama seperti dalam bahasa. Masyarakat Sawahlunto memiliki bahasa khas sendiri yang mereka kenal dengan istilah bahasa tansi yaitu bahasa campuran (mixture), dari berbagai bahasa buruh tambang batubara seperti Minangkabau, Melayu, Jawa, Sunda, Bali, Madura dan Bugis. (Syafril, 2011) Akulturasi juga terlihat dari upacara adat, keseniaan dan makanan daerah yang saling mempengaruhi sehinggga tercipta sikap saling menyukai budaya etnis lain (mutual akulturasi) yang berujung pada terciptanya akulturasi. Hingga saat ini, ketika aktivitas pertambangan berakhir mereka masih tetap hidup bersama sebagai satu kesatuan bahkan mengidentifikasi sebagai orang Sawahlunto.

Keunikan Kota Sawahlonto sebagai kota multietnis ini lah yang dimanfaatkan oleh pemerintahan Kota Sawahlunto sebagai salah satu ikon wisata nya. Sehingga di Kota Tua ini dilakukan berbagai pertunjukan dan pameran untuk menarik kunjungan wisatawan. Seperti pertunjukan kesenian tari piring sebagai kesenian Minangkabau, tari ronggeng dari Jawa, tari tor-tor dari Batak, bahkan juga barongsai dari etnis Tiongha yang dilengkapi dengan berbagai pameran dan festival yang bisa memperkenalkan wajah Kota Sawahlunto dulu dan sekarang.

Potensi budaya lain yang juga diperkuat oleh pemerintahan Sawahlunto adalah pengembangan produksi kerajinan Tenun Silungkang sebagai kekayaan lokal Kota Sawahlunto. Meskipun Tenun Silungkang telah lama menjadi identitas khas dari Kota Sawahlunto, namun selama ini produksinya masih sangat terbatas karena selain prosedur pembuatannya yang sulit, pengrajinnya yang juga masih sangat minim. Maka atas dasat itu pemerintahan Kota Sawahlunto melalukan pembinaan berkala kepada masyarakat Silungkang agar mengembangkan tenun songket sebagai bagian keterampilan daerah, dengan membuat 'Kampung Tenun' guna mengokohkan eksistensi tenun songket sebagai identitas khas Kota Sawahlunto sebagai bagian dari agenda pengembangan pariwisata. Upaya membangkitkan kembali potensi budaya lokal menjadi bagian dari pariwisata menjadi keunikan tersendiri bagi pariwisata kota ini. Wisata bukan hanya aspek fisik semata tetapi juga dibungkus oleh nilai sosio kultural yang bisa menjadi pembeda dari wisata tambang lainnya di dunia. Apalagi dengan memanfaatkan potensi sebagai kota wisata tambang multietnis akibat peninggalan sejarah pertambangan batu bara ratusan tahun lalu, menjadikan Sawahlunto sebagai Kota Wisata Tambang Berbudaya Multietnis yang terunik di Dunia. Keunikan kota tua ini pun mengantarkannya sebagai perwakilan Indonesia untuk diusulkan sebagai situs Warisan Dunia (World Heritage) UNESCO. Sebelum Kota Sawahlunto, sebenarnya telah ada daerah di Asia yang memiliki sejarah hampir mirip dengan Kota Sawahlunto, yaitu Gunkanjima yang terletak di Nagasaki Jepang, sebuah pulau bekas pertambangan batubara yang juga di pugar menjadi kota wisata dan saat ini tumbuh menjadi kawasan industri wisata modern di Jepang, dan pada tahun 2015 lalu dinyatakan sebagai salah satu situs Warisan Dunia UNESCO. (Hashimoto, 2016). Akan tetapi konsep revitalisasi nya jauh berbeda dengan Kota Sawahlunto, karena Sawahlunto lebih mempertahankan sisi tradisional sebuah kota tua yang multietnis, sementara Gunkanjima lebih memilih menjadi kawasan industri wisata modern. 


\section{Bangkitnya Kembali Kesejahteraan Kota Melalui Perkembangan Pariwisata (Sebuah Tinjauan Sosiologis)}

Pengembangan kota wisata tambang berbudaya di Kota Sawahlunto melalui daur ulang lokasi pertambangan batu bara dan menonjolkan aspek budaya lokal yang multietnis ternyata mampu menjadi daya tarik tersendiri bagi wisatawan. Kota yang sempat dijuluki kota mati ini bagai mendapatkan ruh nya kembali. Tidak memerlukan waktu yang lama bagi Kota Sawahlunto untuk berbenah, tahun 2001 pemerintahan merombak rencana pembangunan kota menjadi kota tambang wisata berbudaya dan tahun 2005 mulai menampakkan hasil nyata. Hasil tersebut terlihat dari jumlah pengunjung kota wisata yang mengalami peningkatan secara signifikan dari tahun ke tahun seperti yang terlihat dari tabel berikut ini:

\section{Gambar 1. Jumlah Kunjungan Wisatawan ke Kota Sawahlunto Tahun 2004 s/d 2015}

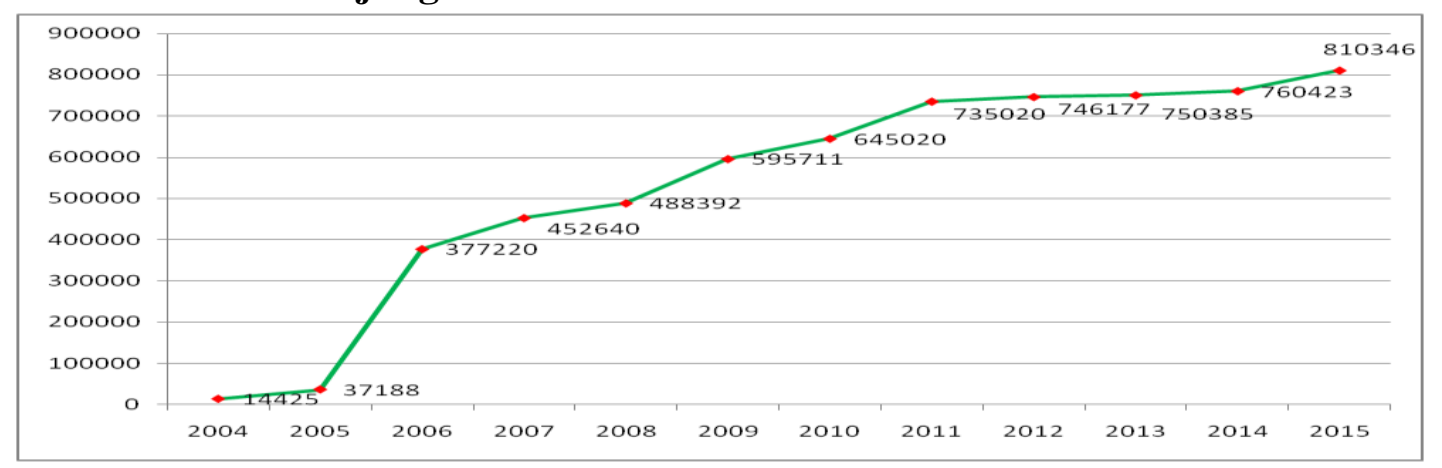

Sumber Data: Dinas Pariwisata Kota Sawahlunto

Data di atas memperlihatkan bahwa agenda perubahan Kota Sawahlunto menjadi Kota Wisata Tambang Berbudaya berhasil mewujudkan misi Kota Sawahlunto saat itu. Terbukti dengan meningkatnya angka kunjungan dari tahun ketahun bahkan dengan grafik yang selalu mengalami peningkatan. Peningkatan paling signifikan terjadi pada tahun 2006, dari jumlah 37188 orang pada tahun 2015, meningkat menjadi 377220 pada tahun 2016 dan secara konsisten meningkat terus hingga akhir tahun 2015. Peningkatan jumlah wisatawan ini berkorelasi positif dengan peningkatan kesejahteraan di Kota Sawahlunto. Di awal penutupan pertambangan, tepatnya pada tahun 2000 angka kemiskinan di Kota ini mencapai $10 \%$ dari total jumlah penduduk. Namun pada tahun 2004 pasca pengembangan wisata tambang angka kemiskinan ini kembali bisa ditekan, mencapai $5.5 \%$ dan terus menurun secara perlahan, seperti yang terlihat pada diagram berikut ini:

\section{Gambar 2. Persentase Penduduk Miskin Kota Sawahlunto Tahun 2013-2015}

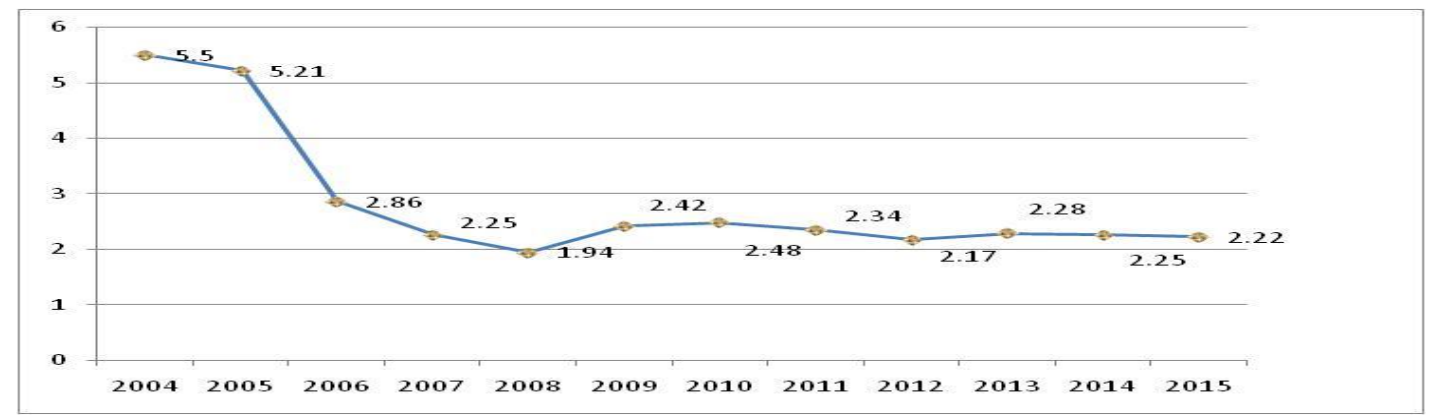

Sumber: BPS Kota Sawahlunto Tahun 2016

Dari grafik di atas terlihat bahwa angka kemiskinan di Kota Sawahlunto cenderung mengalami penurunan dari tahun ke tahun. Pada tahun 2004 masyarakat yang tergolong miskin di Kota Sawahlunto tercatat sebanyak 5.5\% dari total jumlah penduduk. Pada tahun 2005 
angka kemiskinan mengalami penurunan menjadi $5.21 \%$, namun penurunan paling signifikan terjadi pada tahun 2006, dimana angka kemiskinan bisa ditekan sampai $2.86 \%$, ini artinya dalam waktu satu tahun angka kemiskinan mengalami penurunan sebanyak $40 \%$ dari total penduduk miskin di Kota Sawahlunto. Kemudian pada tahun berikutnya angka kemiskinan cenderung konstan berkisar $1.94 \%$ sampai $2.34 \%$. Bahkan di tahun 2015 angka kemiskinan di Kota Sawahlunto hanya berkisar $2.22 \%$. Menariknya dengan angka ini mengantarkan Kota Sawahlunto menjadi kota nomor dua penduduk miskin paling rendah setelah kota Tangerang.

Dari data di atas dapat disimpulkan bahwa penurunan angka kemiskinan di Kota Sawahlunto, seiring dengan meningkatnya jumlah wisatawan ke Kota Wisata Tambang ini. Karena seiring dengan berkembangnya objek wisata dan banyaknya peminat wisata tentu berdampak pada peningkatan perekonomian masyarakat di sekitarnya. Objek wisata tambang ini pada umumnya berada di pusat padat penduduk, secara otomatis akan menciptakan peluang usaha baru bagi masyarakat di sekitarnya terutama usaha jasa pelayanan wisata.

Peningkatan jumlah wisatawan dan penurunan angka kemiskinan di Kota Sawahlunto membuktikan keberhasilan kota ini dalam berbenah diri pasca mengalami keterpurukan secara ekonomi. Hal ini karena kepiawaian pemerintahan Sawahlunto bersama stakeholder dalam memanfaatkan potensi yang ada dari bekas aktivitas penambangan batubara. Ketertarikan pengunjung bukan sekedar pada objek wisata fisik saja, tapi juga wisata sejarah dan pengetahuan karena juga menjual sisi kerasnya kehidupan para buruh tambang tempo dulu.

Wisata tambang menjadi semakin berkembang tatkala dilengkapi dengan pesona budaya multietnis, dengan manyajikan berbagai atraksi budaya, kesenian dari beberapa etnis yang menghuni kota ini. Hal yang paling penting dalam kesuksesan pembangunan wisata ini adalah ketika masyarakat menjadi bagian yang tidak terpisahkan dari agenda pembangunan. Masyarakat dilibatkan dalam setiap rencana pembangunan dan berpartisipasi langsung dalam pembangunan Kota Wisata Tambang dan menikmati langsung hasil dari pembangunan. Hal ini sesuai dengan ungkapan Edi Suharto (2006) bahwa pembangunan ekonomi harus diiringi oleh pembangunan sosial sebagai suatu pendekatan pembangunan yang mempunyai tujuan untuk meningkatkan kualitas kehidupan dan kesejahteraan manusia yang hidup di dalamnya.

Suksesnya Kota Sawahlunto untuk bangkit dari keterburukan tidak terlepas dari peran berbagai aktor yang ada di dalamnya. Tokoh Amran Nur sebagai Walikota Kota Sawahlunto (2003-2013) adalah tokoh sentral yang menjalankan gagasan revitalisasi ini yang kemudian dalam setiap pelaksanannya melibatkan para ahli dan pemangku kebijakan baik yang berasal dari kalangan birokrat, tokoh masyarakat (Tokoh adat dan agama), akademisi maupun anggota masyarakat Kota Sawahlunto sendiri yang terlibat dalam aktivitas pembangunan. Para aktor ini lah yang disebut sebagai agent of change di Kota Sawahlunto yang mampu menangkap kerusakan alam dan sisa tmbang sebagi peluang usaha. Keberhasilan Kota Sawahlunto dalam merevitalisasi wajah kota hingga bermuara pada peningkatan kembali kesejahteraan masyarakat tidak terlepas dari relasi dua hal yaitu sumber daya sejarah Kota Tambang dan aktor yang mampu menangkap sumber daya tersebut untuk mencapai tujuan kesejahteraan.

Aktor dan sumber daya adalah dua hal yang sangat penting dalam mencapai tujuan pembangunan. Sesuai dengan apa yang diungkapkan oleh James S.Coleman dalam teori nya tentang pilihan rasional. Menurutnya bahwa untuk mencapai sebuah tujuan yang ditetapkan telah tersedia berbagai alternatif pilihan/ cara dengan memanfaatkan sumber daya yang dimiliki dengan tetap mempertimbangkan nilai-nilai yang dianut bersama. (Ritzer, 2004). Kepiawaian aktor menetapkan cara untuk memanfaatkan sumber daya ini lah yang pada akhirnya bermuara pada pencapaian tujuan. Artinya aktor dan sumber daya menjadi dua aspek penting dalam pencapai tujuan pembangunan.

Peran aktor dalam memanfaatkan sumber daya inilah yang menjadi modal bagi Kota Sawahlunto untuk bangkit dari keterpurukan. Aktor yang didalam dirinya memiliki kreativitas untuk mencipta bahkan dari sumber yang tidak terfikirkan oleh oranglain. Seperti apa yang 
diungkapkan juga oleh Everatte Hagen bahwa kesuksesan perubahan pembangunan di dalam masyarakat sangat ditentukan oleh aktor di balik perubahan. Aktor yang kreatif dan inovatif, bukan hanya memikirkan dirinya sendiri tetapi juga kesejahteraan orang lain di sekitarnya (Lauer, 1998)

Pada prinsipnya upaya yang dilakukan oleh pemerintah Kota Sawahlunto dalam menghidupkan kembali kota ini sesuai dengan prinsip revitalisasi itu sendiri. Bahwa revitalisasi bukan sesuatu yang hanya berorientasi pada penyelesaian keindahan fisik saja, tapi juga harus dilengkapi dengan peningkatan ekonomi masyarakatnya serta pengenalan budaya yang ada. Untuk melaksanakan revitalisasi perlu adanya keterlibatan masyarakat. Keterlibatan yang dimaksud bukan sekedar ikut serta untuk mendukung program pembangunan tetapi berpartisipasi langsung dalam pembangunan yang berkelanjutan. Atas dasar prinsip ini Kota Sawahlunto mampu menghidupkan kembali wajah kota yang pernah mati.

\section{Penutup}

Perubahan kebijakan Kota Sawahlunto berhasil mengubah wajah Kota Sawahlunto dari Kota Tambang Batubara menjadi Kota Wisata Tambang Berbudaya. Terbukti dari menurunnya angka kemiskinan dari tahun ke tahun, yang beriringan dengan meningkatnya secara signifikan jumlah wisatawan. Keberhasilan ini tidak terlepas dari peran aktor yang yang ada di Kota Sawahlunto dalam memanfaatkan sumber daya lokal yang berasal dari bekas aktivitas pertambangan yang selama terabaikan. Keunikan Kota Wisata Tambang Sawahlunto dibanding Wisata Tambang lain di Dunia adalah konsep wisata budaya multietnis yang juga tercipta dari sejarah pertambangan dari zaman Belanda. Keunikan kota tua ini mengantar kan Kota Sawahlunto saat ini sebagai kota tua yang diusulkan mewakili Indonesia menjadi salah satu situs warisan dunia (World Heritage) UNESCO sekaligus membangkitkan kembali semangat kota tua yang dulu sempat terkubur seiring terkuburnya potensi batubara.

\section{Daftar Pustaka}

BPS. (2015)Sawahlunto Dalam Angka (SDA) tahun 2015. Sawahlunto: Badan Pusat Statistik Kota Sawahlunto.

Danisworo, Mohammad dan Widjaja, Martokusumo. (2002). Revitalisasi Kawasan Kota Sebuah Catatan dalam Pengembangan dan Pemanfaatan Kawasan Kota. www.urdi.org (urban and reginal development institute, 2000). 15 Agustus 2017.

Erman, Erwiza. (2005). Membaranya Batu Bara Konflik Kelas dan Etnik, Ombilin Sawahlunto1892-1996. Jakarta: Penerbit Disentra

Hashimoto, Atsuko dan Tefler J. David. (2017). Transformation of Gunkanjima (Battleship Island): from a Coalmine Island to a Modern Industrial Heritage Tourism Site in Japan. $\begin{array}{lllll}\text { Jurnalof Heritage } \quad \text { Tourisme. } & \text { Volume } & \end{array}$ http://dx.doi.org/10.1080/1743873X.2016.1151884. 21 Agustus 2017

Huberman, Michael dan Miles B. Mattew. (1992). Analisis Data Kualitatif. Jakarta: Universitas Indonesia Press.

Lauer, H, Robert. (1988). Perspektif Tentang Perubahan Sosial. Jakarta: Bian Aksara

Ritzer, George dan Goodman, J. Douglas. (2004). Teori Sosiologi Modern. Jakarta: Prenada Media. 
Soeharto, Edi. (2006). Membangun Masyarakat Memberdayakan Rakyat. Bandung: PT. Refika Aditama.

Syafril, Elsa Putri. (2011). Menggali Bara, Menemu Bahasa: Bahasa Tansi, Bahasa Kreol Buruh dari Sawahlunto. Sawahlunto: Pemerintah Kota Sawahlunto 